\title{
Hydrolytic Degradation of a Resin Composite as a Function of the Curing Tip Distance and Aging
}

\author{
Nádia da Rocha Svizero ${ }^{\mathrm{a}}$, Vanessa de Freitas Carvalho ${ }^{\mathrm{a}}$, Janaina Bechtold ${ }^{\mathrm{b}}$, \\ Roberta Caroline Bruschi Alonso ${ }^{\mathrm{c}}$, Maria Teresa Atta ${ }^{\mathrm{d}}$, Paulo Henrique Perlatti D'Alpino ${ }^{\mathrm{c} *}$ \\ ${ }^{a}$ Hospital de Reabilitação de Anomalias Craniofaciais, University of São Paulo - USP, \\ São Paulo, SP, Brazil \\ ${ }^{b}$ Anhanguera-Uniban University, São Paulo, SP, Brazil \\ 'Biomaterials Research Group, Anhanguera-Uniban University, São Paulo, SP, Brazil \\ ${ }^{d}$ Department of Operative Dentistry, Endodontics and Dental Materials, \\ Bauru School of Dentistry, University of São Paulo - USP, Bauru, SP, Brazil
}

Received: May 2, 2011; Revised: August 2, 2011

\begin{abstract}
The influence of curing tip distance and storage time on the hardness of a composite was evaluated. Composite samples (Filtek Z250) were polymerized at different distances $(5,10$, and $15 \mathrm{~mm}$ ), compared with a control group $(0 \mathrm{~mm})$, and stored in distilled water at $37^{\circ} \mathrm{C}$ for 24 hours. The Knoop-hardness of top and bottom surfaces was assessed $(25 \mathrm{~g} / 30 \mathrm{~s})$. Specimens were stored in distilled water for 6 and 12 months and were retested. Hardness was found to be negatively influenced by both curing tip distance and storage time. Despite similar values at 24 hours, differences in hardness values compared with the control group appeared over time. In comparing both surfaces, hardness proved to be greater at the top surface for all groups. Composites with similar initial hardness values can degrade very differently after water storage. The higher the photoactivation distance and storage time, the worse the mechanical property.
\end{abstract}

Keywords: knoop hardness, dental composite, aging

\section{Introduction}

A minimum light intensity has been reported to ensure an adequate polymerization of composites ${ }^{1}$. In contrast, no agreement has been reached regarding the ideal power density required to yield acceptable levels of polymerization and hardness in resin composites $^{2}$. Such parameters as energy density, irradiance, light source, and exposure time are of particular interest as, in practice, they are under the clinician's control ${ }^{3}$. Ideally, the light tip should be kept as close as possible to the composite surface in order to avoid light dissipation. However, certain clinical situations present a challenge to the utilization of this recommended polymerization technique, such as the accessibility of the light source, the direction of the light, the preparation depth, and the surrounding tissues/ materials ${ }^{4}$. In these instances, a reduced monomer conversion may occur. Resin conversion is an essential component to ensuring optimal mechanical properties that resist mechanical and chemical deterioration $^{5,6}$. Depending on the clinical scenario, the amount of light that penetrates the bulk material can be attenuated or scattered; as a consequence, fewer molecules of camphorquinone are activated, reducing the extent of the reaction and also limiting the depth of the cure ${ }^{7}$. Underperforming the polymerization of a resin composite adversely affects its physical properties ${ }^{8,9,10}$, reduces the bond strength ${ }^{9,10}$, increases the marginal wear ${ }^{8}$, increases bacterial colonization of the composite ${ }^{11}$, and decreases the biocompatibility by potentially increasing the DNA damage that results from monomer leaching ${ }^{11,12}$.

Clinical concerns have also been expressed about the depth of proximal boxes in Class II preparations, for which the distance between the light guide and the material surface is generally quite considerable $^{13}$. An incomplete curing of the restoration at the deepest areas in that particular clinical situation may lead to the development of secondary caries and marginal failures ${ }^{14}$. Inappropriately polymerized composites may also induce increased rates of water sorption and the releasing of various components ${ }^{15}$. Water molecules are known to serve as precursors to a variety of chemical and physical processes and to have deleterious effects on the structure and function of the resin matrix ${ }^{16}$. Composite hardness may be permanently altered by these events ${ }^{17}$. In addition, it may also lead to advanced restoration failure $^{18}$. Clinically, it is impossible to evaluate the hardness at the lower surface but it is therefore claimed to be more relevant to composite longevity ${ }^{6}$. On the other hand, water may have a beneficial effect on resin composites, as water molecules are absorbed into the resin matrix, making the composite more flexible, resulting in an apparent increase in mechanical properties ${ }^{19}$.

Composite composition determines the hydrophilicity, mobility and kinetic parameters ${ }^{5}$. The BisGMA monomer contains pendant hydroxyl groups within its molecular backbone ${ }^{20}$. Due to these polar groups, polymers made with this monomer tend to be somewhat hydrophilic and susceptible to increased water sorption ${ }^{21}$. Various methods have been employed in order to reduce the hydrophilicity of BisGMA-based composites ${ }^{20}$. In the process, ethoxylated bisphenol-A (BisEMA), a non-hydroxylated monomer, was developed. Compared to BisGMA, BisEMA is less hydrophilic and exhibits a reduced viscosity $^{20}$. 
This study evaluated the influence of different curing tip distances on the microhardness of a commercial BisEMA-based resin composite, known to contain camphorquinone as a photoinitiator. The results were compared to the values obtained when the curing tip was positioned as close as possible to the composite surface. The microhardness assessment was repeated after 6 and 12 months of storage in distilled water. The first research hypothesis to be tested was that the hardness values for the top surface would be similar to the values of the control group ( $0 \mathrm{~mm}$ distance) when different curing tip distances are used to polymerize the composite. The second research hypothesis was that the values obtained for the bottom surface when using different curing tip distances would be equivalent to the values obtained for the control group. The third research hypothesis to be tested was that no difference in hardness would be found when values for the top surface are compared with those for the bottom surface, irrespective of the curing tip distances tested. Finally, a fourth hypothesis, namely that no difference would be found in microhardness values after 6 and 12 months of storage in distilled water, was tested.

\section{Material and Methods}

3M ESPE Filtek Z250 (St. Paul, MN, USA) resin composite was the restorative material tested (shade A3, lot \# $8 \mathrm{NW}$ ). Material was inserted into a Teflon mold $(2.5 \mathrm{~mm}$ thick, $6 \mathrm{~mm}$ in diameter $)$ and photoactivated according to the manufacturer's directions (20 seconds curing time). A pilot study was conducted in order to calibrate the operator and determine the sample size, as repeated indentations would be obtained after 6 and 12 months. The material was photoactivated, simulating the curing scenario in a $2.5-\mathrm{mm}$ deep preparation, in which different curing tip distances $(5,10$, and $15 \mathrm{~mm}$ ) were used to polymerize the composite. The results were compared to the mean microhardness values obtained for the control group $(0 \mathrm{~mm})$. After insertion, a polyester strip was applied to the surface of the unpolymerized material, and a microscope slide was pressed against the composite surface in order to form the material into the shape of the inner portion of the mold. The same restorative material volume was obtained along flat top and bottom surfaces. The excess material was removed, and the specimens were then photoactivated at the top surface. A quartz-tungsten-halogen (QTH) curing light was used to polymerize the specimens (Ivoclar Vivadent Astralis 3, Liechtenstein). The spectral irradiant distribution of the light was measured using a laboratory-grade spectral radiometer (Spectrometer Ocean Optics, Inc., USB 2000, Dunedin, FL, USA). The area under the spectral profile was integrated from 350 to $600 \mathrm{~nm}$ in order to determine the total power emitted. The power was then divided by the cross sectional area of the fiberoptic tip $\left(\mathrm{cm}^{2}\right)$. Light intensity was monitored throughout the experiment in order to ensure that a consistent intensity was maintained.

Cylindrical specimens were divided into 4 groups, with five specimens in each group, according to the different curing tip distances used. After photoactivation, the specimens were removed from the molds and the top surface was identified with an indelible mark. A single operator prepared the specimens. The specimens were then stored in lightproof recipients for 24 hours. After this period, a microhardness test was performed into a digital Knoop hardnessmeasuring instrument under load (Shimadzu HMV-M Microhardness Tester; Newage Testing Instruments, Inc., Southampton, PA, USA). Ten randomized indentations ( 5 on both the top and bottom surfaces) were made with a $25 \mathrm{~g}$ load for 30 seconds with a dwell time of 15 seconds. For randomization purposes, specimens were arbitrarily rotated prior to indentations being made. The microhardness assessment was repeated after 6 and 12 months of storage in distilled water.

\subsection{Statistical analysis}

Statistical analysis was conducted using a three-way ANOVA and Tukey's post hoc test for pair-wise comparisons. All statistical testing was performed at a preset alpha of 0.05. A normal distribution of data was confirmed by the Komogorov-Smirnov test and the Shapiro-Wilk test. Three-way ANOVA was performed in order to evaluate the influence of the three variables tested: light-curing tip distance $(0,5,10$, and $15 \mathrm{~mm})$, evaluation time ( 24 hours, 6 months, and 12 months), and surfaces (top and bottom).

\section{Results}

The spectral emission profile of light unit used in this study is presented in Figure 1. The QTH light generated a relatively wide spectral emission profile, and a moderate power density level $\left(600 \mathrm{~mW} . \mathrm{cm}^{-2}\right)$. A pronounced peak was observed at $490 \mathrm{~nm}$, demonstrating the effectiveness of the filter required to restrict the emitted light to the blue region of the spectrum, in which the photoinitiator camphorquinone characteristically absorbs energy (425 to $490 \mathrm{~nm}$, with a peak at approximately $465 \mathrm{~nm})^{2}$. The power density and energy dose assessed were as follows: at $0 \mathrm{~mm}, 600 \mathrm{~mW} . \mathrm{cm}^{-2}\left(12 \mathrm{~J} . \mathrm{cm}^{-2}\right)$; at $5 \mathrm{~mm}$, $320 \mathrm{~mW} . \mathrm{cm}^{-2}\left(6.4 \mathrm{~J} . \mathrm{cm}^{-2}\right)$; at $10 \mathrm{~mm}, 150 \mathrm{~mW} . \mathrm{cm}^{-2}\left(3 \mathrm{~J} . \mathrm{cm}^{-2}\right)$; and at $15 \mathrm{~mm}, 100 \mathrm{~mW} . \mathrm{cm}^{-2}\left(2 \mathrm{~J} . \mathrm{cm}^{-2}\right)$.

Figures 2 and 3 display the microhardness mean values of the top and bottom surfaces according to evaluation times. After 24 hours, at the top surface, the highest microhardness mean values were observed in the $0-, 5-$, and $10-\mathrm{mm}$ groups $(75.9 \pm 2.9 ; 76.5 \pm 2.2$; and $77.5 \pm 2.5$, respectively). The 15 -mm group demonstrated the lowest mean value $(70.5 \pm 2.8)$. Statistical analysis indicated a statistically significant difference $(\mathrm{p}<0.05)$ when the hardness mean values for the 15-mm group were compared with those obtained for the control group $(0 \mathrm{~mm})$. After 6 and 12 months, all of the groups demonstrated reduced hardness values. At these evaluation times, the highest values were observed for the control group at the top surface (71.0 \pm 0.7 and $67.6 \pm 1.3$, respectively). In both cases, a statistically significant difference was found when the mean values obtained for the control group were compared to the values for the 10-mm group (65.2 \pm 2.4 and $58.9 \pm 3.3$ for 6 and 12 months, respectively) and the 15-mm group (55.1 \pm 1.0 and $53.1 \pm 0.7$ for 6 and 12 months, respectively).

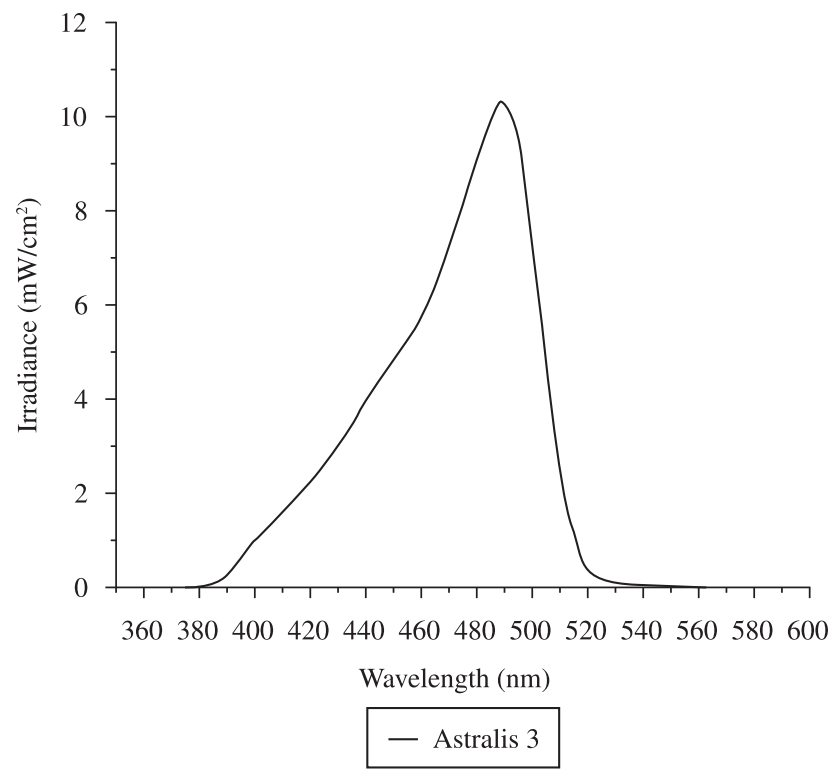

Figure 1. Spectral irradiance of the light curing unit used. 


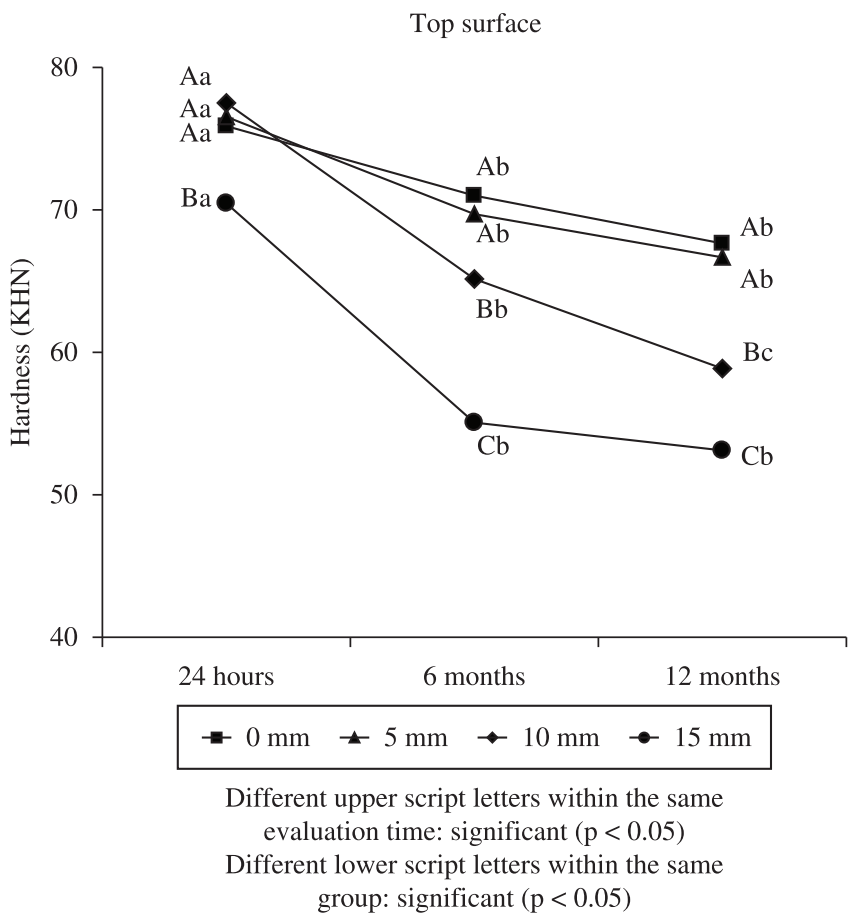

Figure 2. Results and statistical analysis for the top surface.

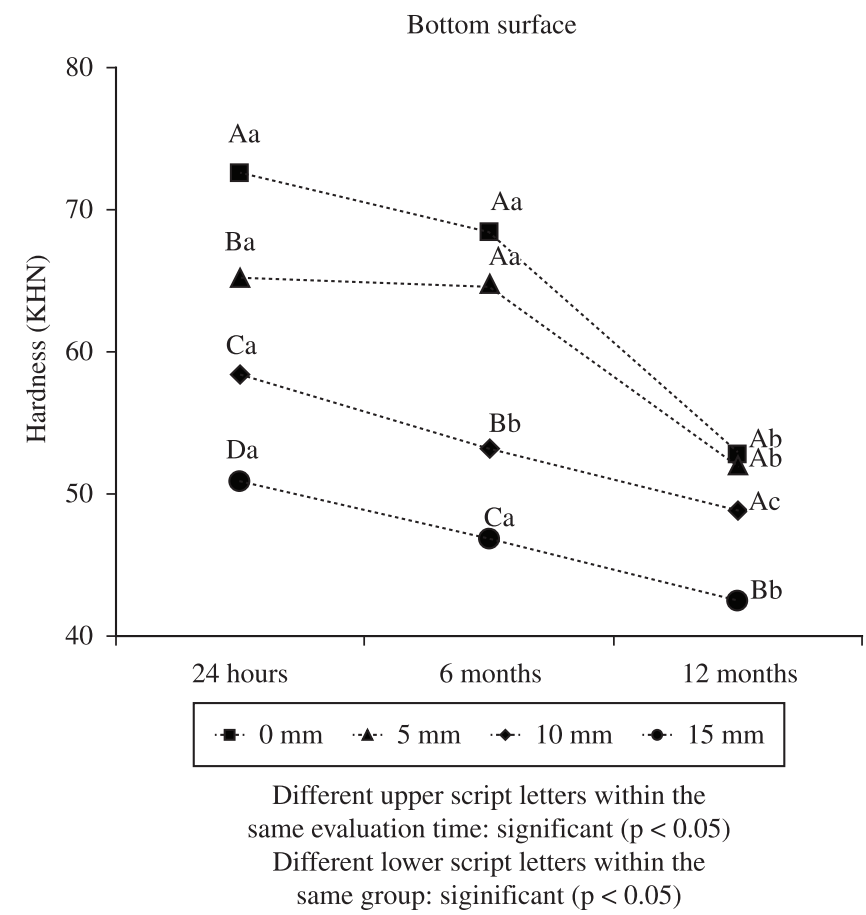

Figure 3. Results and statistical analysis for the bottom surface.

For the bottom surface, the 0 -mm group demonstrated the highest hardness mean value $(72.6 \pm 2.2)$, while the 15 -mm group displayed the lowest hardness mean value $(50.8 \pm 2.1)$ after 24 hours. The hardness of the control group proved to be significantly higher $(\mathrm{p}<0.05)$ when compared with all of the tip distances tested. On the other hand, as the hardness values for the 0-mm group decreased after 6 months, a statistically significant difference was determined when the mean values were compared with the hardness values for the $10-\mathrm{mm}$ group and the $15-\mathrm{mm}$ group $(\mathrm{p}<0.05)$. After 12 months, the microhardness mean values of the $0-\mathrm{mm}$ group also decreased (after 6 months, from 72.6 to 68.4 ; and after 12 months, to 52.8), and a statistically significant difference was only observed when the values for the control group were compared with the hardness values for the 15-mm group ( $<<0.05)$.

When the hardness values at different evaluation times were compared (using 24 hours as the control), significantly lower hardness mean values were observed for the top surface after 6 and 12 months (Figure 2), irrespective of the experimental groups tested $(\mathrm{p}<0.05)$. For the bottom surface (Figure 3), statistically equivalent mean values were only observed after 6 months for 0 - and 5-mm groups, as opposed to the values obtained at 24 hours $(p>0.05)$.

Table 1 presents the top-to-bottom variation in the microhardness mean values for each material/curing unit combination. Statistically significant top-to-bottom differences were observed for all of the groups, aside from the $0-\mathrm{mm}$ group at 24 hours and 6 months $(p>0.05)$. Statistical analysis also demonstrated that the interaction tip distance $\mathrm{x}$ evaluation time $\mathrm{x}$ surface significantly influenced the microhardness values $(\mathrm{p}=0.0001)$.

\section{Discussion}

The first and second hypotheses, namely that the microhardness values observed for both the top and bottom surfaces when different curing tip distances are used to polymerize a commercial resin composite would be similar to the values observed for the control group $(0 \mathrm{~mm})$, were not validated. For the top surface, after 24 hours, significantly lower hardness values were observed when the curing tip was positioned $15 \mathrm{~mm}$ from the composite surface $(70.5 \pm 2.8)$, compared with the values observed for the control group $(75.9 \pm 2.9)$. After 6 months, the mean hardness values decreased for all of the groups; significantly lower values were observed for the 10- and 15 -mm groups $(65.2 \pm 2.4$ and $55.1 \pm 1.0$, respectively) than for the 0 -mm group $(71.0 \pm 0.7)$. The values obtained after 12 months were even lower for all of the groups, but a statistically significant difference between the 10- and 15-mm groups and the control group remained. For the bottom surface, after 24 hours, the hardness mean values were lower, the farther away the curing tip was positioned. Statistical analysis demonstrated a statistically significant difference when the values for all of the experimental groups were compared with the values the 0 -mm group. After 6 months, the hardness values were statistically equivalent to the values observed at the 24 hours evaluation time (with the exception of the 10-mm group); however, after 12 months, all of the values were significantly lower than the 24 hours hardness values.

Hardness values decreased for both surfaces as the curing tip was positioned farther away from the composite. The difference in hardness values among these groups appeared over time. As the 0 -, 5- and 10-mm groups exhibited similar hardness mean values at 24 hours, equivalent behavior with respect to this particular mechanical property tested after 6 and 12 months among these groups might be expected. However, the reductions in hardness values in the 5- and 10-mm groups after 6 and 12 months were greater than those in the control group. The present study indicates that, although hardness tests have been used to evaluate the physical properties of composite dental materials and to predict the clinical performance ${ }^{22}$, the initial mean values do not discriminate between polymers of different extents of crosslinking. Although the physical and mechanical properties of resin composites are also strongly influenced by the degree of conversion $^{23}$, increased crosslink density has also been associated with increased physical properties and stability ${ }^{24}$. The degree of 
Table 1. Top-to-bottom variation in the microhardness mean values (mean $\pm \mathrm{sd}$ ).

\begin{tabular}{|c|c|c|c|c|c|c|}
\hline & \multicolumn{2}{|c|}{24 hours } & \multicolumn{2}{|c|}{6 months } & \multicolumn{2}{|c|}{12 months } \\
\hline & Top & Bottom & Top & Bottom & Top & Bottom \\
\hline $0 \mathrm{~mm}$ & 75.9 (2.9) & $72.6(2.2)$ & $71.0(0.7)$ & $68.4(0.6)$ & $67.6(1.3)$ & $52.8(0.9)$ \\
\hline $5 \mathrm{~mm}$ & $76.5(2.2)$ & $65.2(2.4)$ & $69.7(0.7)$ & $64.8(2.4)$ & 66.7 (1.3) & $52.0(1.1)$ \\
\hline $10 \mathrm{~mm}$ & 77.5 (2.5) & $58.6(2.8)$ & $65.2(2.4)$ & $53.2(1.5)$ & $58.9(3.3)$ & $48.8(3.1)$ \\
\hline $15 \mathrm{~mm}$ & $70.5(2.8)$ & $50.8(2.1)$ & $55.1(1.0)$ & $46.8(0.9)$ & $53.1(0.7)$ & $42.4(0.5)$ \\
\hline
\end{tabular}

Highlighted cells: top-to-bottom variation: no significant $(\mathrm{p}>0.05)$.

conversion is well correlated with the quantity of double bonds remaining in the polymer, a factor of considerable importance, as it influences the mechanical properties of a given composite ${ }^{25}$. However, the extent of crosslinking of the matrix appears to be more important in predicting composite hardness behavior over time. Care must be taken when considering hardness to be indicative of the degree of conversion, as in some cases, samples with similar conversions can have different cross-linking densities, which, in turn, can affect hardness ${ }^{26}$. Conversion is an average measure and fails to take into account the fact that a material with non-uniform conversion may demonstrate the same quantity of remaining double bonds as a more homogeneously polymerized material ${ }^{27}$. In addition, polymers differing in linearity and therefore having different crosslink densities may possess similar conversion values ${ }^{28}$.

An initial microhardness test was performed after 24 hours, as the increase in post irradiation hardness is rapid over the first hour slowing to achieving a maximum value within 24 hours $^{29}$. It has been demonstrated that at early stages of polymerization, pendant carbon double bonds are preferentially consumed in so-called primary cyclization reactions, and high degrees of conversion are reached, substantially increasing crosslinking ${ }^{30}$. In these reactions, microgels are created, resulting in a heterogeneous polymer network in which crosslinked areas and more highly crosslinked microgel regions coexist $\mathrm{t}^{27}$. Thereafter, a secondary cycle occurs, and radicals react with pendant double bonds on different kinetic chains with which they are already crosslinked ${ }^{27}$.

The third hypothesis, which states that there is no difference in microhardness when the hardness values for the top surface are compared with values observed for the bottom surface, was also rejected. The polymerization process explains the results obtained for the top and bottom surfaces. The resin composite at the surface receives the full power density with minimal light attenuation during irradiation. At the irradiated surface the polymerization process proceeds very quickly because virtually all of the photoinitiator is activated ${ }^{31}$. However, deeper in the resin-based photoactivated material, light attenuation and scattering cause a decrease in conversion, as fewer molecules of camphorquinone are activated due to the absorption and scattering of the light, leading to a considerable reduction in the extent of the reaction ${ }^{32}$. The rate of polymerization is thus reduced, compared with the rate at the surface ${ }^{33}$. Depending on the number of photons, less light will be able to penetrate to deeper depths of the restorative material, thereby decreasing the probability of raising a large number of photoabsorbing molecules to an excited state, thus decreasing the total conversion ${ }^{32}$.

The results of the present study indicated a sensitivity to curing tip distance. Comparing the hardness values of both surfaces, only the 0 -mm group exhibited a significantly equivalence between the surfaces, with equivalent values remaining after 6 months of storage in distilled water (Table 1). Thus, the fourth research hypothesis was not accepted. Lower light intensity at different distances possibly activates a smaller quantity of initiators, generating a greater number of unreacted monomers and a less crosslinked polymer with linear characteristics.

In an aqueous environment, composites absorb water and not only elute unreacted monomers ${ }^{34}$, but elements from filler particles and polymerization promoters ${ }^{35}$ as well. These uncured monomers may be leached at a higher rate in the mouth due to the greater solubility ${ }^{36}$ of these monomers in saliva, compared with the rate observed when they are exposed to water molecules. Depending on the material, a larger number of air voids can form during the polymerization of resin composites due to shrinkage ${ }^{37}$. Clinically, the release of the composite components influences the initial dimensional change of the composite as well as the clinical performance and the long-term esthetic of the restorations ${ }^{34}$. The water is primarily absorbed by the resin matrix ${ }^{38}$. The sorption of water is described by a dual-mode theory, which assumes that dissolution may occur in the polymer matrix and/or entrapment as a result of clustering water molecules ${ }^{39}$ in polymer voids by breaking down the chemical bonds in the resin or softening through the plasticizing action of water ${ }^{40}$. In light of the fact the filler particles do not absorb a significant amount of water, the most probable site at which additional water is accommodated is in the interface between the inorganic filler particle and the polymer matrix ${ }^{39}$. The findings of Toledano et al. ${ }^{37}$ suggest that the matrix and the filler particles are not always effectively coupled. In general, water sorption is a diffusion-controlled process ${ }^{37}$, and the diffusion coefficient of water in resin composites tends to increase, followed by an equilibrium in water sorption values ${ }^{34}$.

New formulations of monomers were developed by modifying the chemical structure of certain monomers and/or replacing them. The structure of BisEMA is nearly identical to that of BisGMA, aside from the absence of hydroxyl groups ${ }^{5}$. Replacing BisGMA with BisEMA in composites containing TEGDMA resulted in a higher conversion but no improvement in flexural and diametral tensile strengths ${ }^{41}$. Another study ${ }^{5}$ also demonstrated that mixtures of BisGMA and TEGDMA present an increased crosslink density and a higher degree of conversion than what is observed for mixtures of BisGMA and BisEMA. The lower molecular weight of TEGDMA and the synergic effect with BisGMA have been explained to influence the kinetic parameters contributing to a higher conversion. Furthermore, an internal plasticizing effect has been attributed to BisEMA as a result of its high molecular weight, which reduces the crosslink density of the polymer ${ }^{42}$. Findings of the present study demonstrate that an extreme curing tip distance results in significantly higher softening than for the control group. The authors of previous studies testing different curing tip distances speculate that the higher softening may be associated with relatively few centers of polymer growth that favor the formation of a relatively linear polymer structure ${ }^{33}$. Crosslinked dimethacrylate networks swell when exposed to solvents that penetrate the resin matrix and expand the openings among chains ${ }^{43}$. Thus, during this relatively short period of immersion, residual monomers with a plasticizing effect on the resin matrix may have been released, decreasing its mechanical properties. 
This study also demonstrates that, in spite of similar initial hardness values, the composite can degrade very differently after water storage. It also agreed with previous findings, indicating that significant reductions in the mechanical properties of composites occur only after 7 days of solvent immersion ${ }^{44}$. While the ideal curing tip position appears to be as close to the material as possible $e^{45}$ this position is not possible in all situations. Certain cavity designs and restorative procedures do not allow polymerization within this distance. In these cases, the tip of the appliance cannot be positioned close to the resin composite during polymerization due to such factors as cuspal tips, proximal restorations, or the position of the tooth in the arch. Deeper in these cavities, the restoration must be built up in increments. Each increment should not exceed 2.0-2.5 mm and must be properly cured prior to insertion of the next increment ${ }^{13}$. Although limitations exist, the mechanical properties can be maintained while the cavity is filled and cured.

\section{Conclusions}

It can be concluded that, within the conditions of this study, different curing tip distances used to polymerize a BisEMAbased composite influence the microhardness. The synergic effect between curing tip distance and water storage was also determined to negatively affect the composite hardness. Also proven was the fact that despite similar initial hardness values, the composite can degrade very differently during water storage. The best compromise between hardness and curing tip distance was observed when the tip was placed close to the composite.

\section{References}

1. Felix CA and Price RB. The effect of distance from light source on light intensity from curing lights. Journal of Adhesive Dentistry. 2003; 5(4):283-91. PMid:15008335.

2. D'Alpino PH, Svizero NR, Pereira JC, Rueggeberg FA, Carvalho RM and Pashley DH. Influence of light-curing sources on polymerization reaction kinetics of a restorative system. American Journal of Dentistry. 2007; 20(1):46-52. PMid:17380808.

3. Halvorson RH, Erickson RL and Davidson CL. Energy dependent polymerization of resin-based composite. Dental Materials. 2002; 18(6):463-9. http://dx.doi.org/10.1016/S0109-5641(01)00069-0

4. Emami N, Soderholm KJ and Berglund LA. Effect of light power density variations on bulk curing properties of dental composites. Journal of Dentistry. 2003; 31(3):189-96. http://dx.doi.org/10.1016/S03005712(03)00015-0

5. Goncalves F, Kawano Y, Pfeifer C, Stansbury JW and Braga RR. Influence of bisgma, tegdma, and bisema contents on viscosity, conversion, and flexural strength of experimental resins and composites. European Journal of Oral Sciences. 2009; 117(4):442-6. PMid:19627357. http://dx.doi. org/10.1111/j.1600-0722.2009.00636.x

6. Quance SC, Shortall AC, Harrington E and Lumley PJ. Effect of exposure intensity and post-cure temperature storage on hardness of contemporary photo-activated composites. Journal of Dentistry. 2001; 29(8):553-60. http://dx.doi.org/10.1016/S0300-5712(01)00045-8

7. Rueggeberg F. Contemporary issues in photocuring. Compendium of Continuim Education in Dentistry. 1999; 25:S4-S15.

8. Ferracane JL, Mitchem JC, Condon JR and Todd R. Wear and marginal breakdown of composites with various degrees of cure. Journal of Dental Research. 1997; 76(8):1508-16. PMid:9240388. http://dx.doi.org/10.11 77/00220345970760081401

9. Xu X, Sandras DA and Burgess JO. Shear bond strength with increasing light-guide distance from dentin. Journal of Esthetic and Restorative Dentistry. 2006; 18(1):19-27; discussion 28. PMid:16426505. http:// dx.doi.org/10.2310/6130.2006.00007
10. Staudt CB, Krejci I and Mavropoulos A. Bracket bond strength dependence on light power density. Journal of Dentistry. 2006; 34(7):498502. PMid:16386827. http://dx.doi.org/10.1016/j.jdent.2005.11.006

11. Brambilla E, Gagliani M, Ionescu A, Fadini L and Garcia-Godoy F. The influence of light-curing time on the bacterial colonization of resin composite surfaces. Dental Materials. 2009; 25(9):1067-72. PMid:19375790. http://dx.doi.org/10.1016/j.dental.2009.02.012

12. Knezevic A, Zeljezic D, Kopjar N and Tarle Z. Cytotoxicity of composite materials polymerized with led curing units. Oper Dent. 2008; 33(1):23-30. PMid:18335729. http://dx.doi.org/10.2341/07-16

13. Cenci M, Demarco F and de Carvalho R. Class ii composite resin restorations with two polymerization techniques: Relationship between microtensile bond strength and marginal leakage. Journal of Dentistry. 2005; 33(7):603-10. PMid:16005800. http://dx.doi.org/10.1016/j. jdent.2005.01.001

14. Neme AM, Maxson BB, Pink FE and Aksu MN. Microleakage of class ii packable resin composites lined with flowables: An in vitro study. Operative Dentistry. 2002; 27(6):600-5. PMid:12413226.

15. Pearson GJ and Longman CM. Water sorption and solubility of resinbased materials following inadequate polymerization by a visible-light curing system. Journal of Oral Rehabilitation. 1989; 16(1):57-61. PMid:2526208. http://dx.doi.org/10.1111/j.1365-2842.1989.tb01317.x

16. Ferracane JL. Hygroscopic and hydrolytic effects in dental polymer networks. Dental Materials. 2006; 22(3):211-22. PMid:16087225. http:// dx.doi.org/10.1016/j.dental.2005.05.005

17. Moon HJ, Lee YK, Lim BS and Kim CW. Effects of various light curing methods on the leachability of uncured substances and hardness of a composite resin. Journal of Oral Rehabilitation. 2004; 31(3):258-64. PMid:15025659. http://dx.doi.org/10.1111/j.1365-2842.2004.01172.x

18. Fan PL, Wozniak WT, Reyes WD and Stanford JW. Irradiance of visible light-curing units and voltage variation effects. Journal of American Dental Association. 1987; 115(3):442-5. PMid:3476666.

19. Drummond JL. Degradation, fatigue, and failure of resin dental composite materials. Journal of Dental Research. 2008; 87(8):710-9. PMid:18650540. PMCid:2561305. http://dx.doi.org/10.1177/154405910808700802

20. Kerby RE, Knobloch LA, Schricker S and Gregg B. Synthesis and evaluation of modified urethane dimethacrylate resins with reduced water sorption and solubility. Dental Materials. 2009; 25(3):302-13. PMid:18799211. http://dx.doi.org/10.1016/j.dental.2008.07.009

21. Shobha HK, Sankarapandian M, Kalachandra S, Taylor DF and McGrath JE. Structure property relationship among novel dental composite matrix resins. Journal of Materials Science: Materials in Medicine. 1997; 8(6):385-9. PMid:15348741. http://dx.doi.org/10.1023/A:1018541102275

22. Yoldas $\mathrm{O}$, Akova $\mathrm{T}$ and Uysal $\mathrm{H}$. Influence of different indentation load and dwell time on knoop microhardness tests for composite materials. Polymer Testing. 2004; 23:343-46.

23. Ferracane JL. Correlation between hardness and degree of conversion during the setting reaction of unfilled dental restorative resins. Dental Materials. 1985; 1(1):11-4. http://dx.doi.org/10.1016/S01095641(85)80058-0

24. Asmussen E and Peutzfeldt A. Influence of selected components on crosslink density in polymer structures. European Journal of Oral Sciences. 2001; 109(4):282-5. PMid:11531075. http://dx.doi.org/10.1034/ j.1600-0722.2001.00057.x

25. Munksgaard EC, Peutzfeldt A and Asmussen E. Elution of tegdma and bisgma from a resin and a resin composite cured with halogen or plasma light. European Journal of Oral Sciences. 2000; 108(4):341-5. PMid:10946770. http://dx.doi.org/10.1034/j.1600-0722.2000.108004341.x

26. Obici AC, Sinhoreti MA, Frollini E, Correr-Sobrinho L and Consani S. Degree of conversion and knoop hardness of z250 composite using different photo-activation methods. Polymer Testing. 2005; 24(814-18.

27. Soh MS and Yap AU. Influence of curing modes on crosslink density in polymer structures. Journal of Dentistry. 2004; 32(4):321-6. PMid:15053916. http://dx.doi.org/10.1016/j.jdent.2004.01.012 
28. Asmussen E and Peutzfeldt A. Influence of pulse-delay curing on softening of polymer structures. Journal of Dental Research. 2001; 80(6):1570-3. PMid:11499515. http://dx.doi.org/10.1177/0022034501 0800061801

29. Pilo R and Cardash HS. Post-irradiation polymerization of different anterior and posterior visible light-activated resin composites. Dental Materials. 1992; 8(5):299-304. http://dx.doi.org/10.1016/01095641(92)90104-K

30. Watts DC and Cash AJ. Determination of polymerization shrinkage kinetics in visible-light-cured materials: Methods development. Dental Materials. 1991; 7(4):281-7. http://dx.doi.org/10.1016/S01095641(05)80030-2

31. Stansbury JW, Trujillo-Lemon M, Lu H, Ding X, Lin Y and Ge J. Conversion-dependent shrinkage stress and strain in dental resins and composites. Dental Materials. 2005; 21(1):56-67. PMid:15681003. http:// dx.doi.org/10.1016/j.dental.2004.10.006

32. Silikas N, Eliades G and Watts DC. Light intensity effects on resincomposite degree of conversion and shrinkage strain. Dental Materials. 2000; 16(4):292-6. http://dx.doi.org/10.1016/S0109-5641(00)00020-8

33. Asmussen E and Peutzfeldt A. Polymer structure of a light-cured resin composite in relation to distance from the surface. European Journal of Oral Sciences. 2003; 111(3):277-9. PMid:12786961. http://dx.doi. org/10.1034/j.1600-0722.2003.00044.x

34. Sideridou I, Achilias DS, Spyroudi C and Karabela M. Water sorption characteristics of light-cured dental resins and composites based on bisema/pcdma. Biomaterials. 2004; 25(2):367-76. http://dx.doi.org/10.1016/ S0142-9612(03)00529-5

35. Ferracane JL. Elution of leachable components from composites. Journal of Oral Rehabilitation. 1994; 21(4):441-52. PMid:7965355. http://dx.doi. org/10.1111/j.1365-2842.1994.tb01158.x

36. Larsen IB and Munksgaard EC. Effect of human saliva on surface degradation of composite resins. Scandinavian Journal of Dental Research. 1991; 99(3):254-61. PMid:1831287.

37. Toledano M, Osorio R, Osorio E, Fuentes V, Prati C and Garcia-Godoy F. Sorption and solubility of resin-based restorative dental materials.
Journal of Dentistry. 2003; 31(1):43-50. http://dx.doi.org/10.1016/ S0300-5712(02)00083-0

38. Braden M and Clarke RL. Water absorption characteristics of dental microfine composite filling materials. I. Proprietary materials. Biomaterials. 1984; 5(6):369-72. http://dx.doi.org/10.1016/01429612(84)90038-3

39. Kalachandra S and Turner DT. Water sorption of polymethacrylate networks: Bis-gma/tegdm copolymers. Journal of Biomedical Materials Research. 1987; 21(3):329-38. PMid:2951387. http://dx.doi.org/10.1002/ jbm.820210306

40. Mohsen NM and Craig RG. Hydrolytic stability of silanated zirconia-silica-urethane dimethacrylate composites. Journal of Oral Rehabilitation. 1995; 22(3):213-20. PMid:7769516. http://dx.doi. org/10.1111/j.1365-2842.1995.tb01566.x

41. Stansbury JW. Synthesis and evaluation of new oxaspiro monomers for double ring-opening polymerization. Journal of Dental Research. 1992; 71(7):1408-12. PMid:1629456. http://dx.doi.org/10.1177/00220345920 710070901

42. Sideridou I, Tserki V and Papanastasiou G. Study of water sorption, solubility and modulus of elasticity of light-cured dimethacrylatebased dental resins. Biomaterials. 2003; 24(4):655-65. http://dx.doi. org/10.1016/S0142-9612(02)00380-0

43. Peutzfeldt A. Resin composites in dentistry: The monomer systems. European Journal of Oral Science. 1997; 105(2):97-116. PMid:9151062. http://dx.doi.org/10.1111/j.1600-0722.1997.tb00188.x

44. Lin CT, Lee SY, Keh ES, Dong DR, Huang HM and Shih YH. Influence of silanization and filler fraction on aged dental composites. Journal of Oral Rehabilitation. 2000; 27(11):919-26. PMid:11106982. http://dx.doi. org/10.1046/j.1365-2842.2000.00573.x

45. Caldas DB, De Almeida JB, Correr-Sobrinho L, Sinhoreti MA and Consani S. Influence of curing tip distance on resin composite knoop hardness number, using three different light curing units. Operative Dentistry. 2003; 28(3):315-20.PMid:12760705. 